\title{
"With Old Plays You Have So Long Been Cloyed": James Shirley's Influence on Aphra Behn
}

\author{
Teresa Grant
}

\begin{abstract}
This article emphasises the unrecognised popularity of the Caroline playwright James Shirley's drama on the Restoration stage, demonstrating that - after Fletcher - Shirley, Shakespeare and Jonson pegged pretty level in the 1660s when it came to revivals. Aphra Behn's use of Shirley's The Lady of Pleasure (printed 1637) in her later play, The Lucky Chance (performed 1686), raises questions about why neither it, nor Shirley's popular The Bird in a Cage (printed 1633) were revived in the Restoration. Behn must have been reading Shirley in the 1680s since there are direct verbal echoes in her play, arguing for a direct engagement with earlier drama. Scholars repeatedly connect The Bird in a Cage to Behn because Shirley's playlet leaves room for a lesbian desire which reverberates also within Behn's poetry and other drama. Shirley and Behn also share an interest in the politics of transactional sex, themes that run through both Shirley plays and also in so much of Behn's writing. The Lucky Chance follows both Shirley plays in showing the negotiations necessary for women to remain both independent and virtuous in a system stacked against them.
\end{abstract}

\section{Keywords}

James Shirley, Aphra Behn, Restoration stage, The Bird in a Cage, The Lady of Pleasure, The Lucky Chance

This article was supported by the Czech Science Foundation project GA19-07494S. English Theatre Culture 1660-1737. 
In one of the few essays on Restoration adaptations of earlier plays which does not wholly focus on Shakespeare, Sandra Clark notes that, "three oeuvres stand out: those of Shakespeare, the Beaumont and Fletcher team, and Jonson" (CLARK 2001: 275). It was "undeniably the plays of Beaumont and Fletcher that were most popular in the theatre, particularly in the early years" (CLARK 2001: 284) of the Restoration, but Clark also signals for special mention "plays by the now neglected Caroline writers, Shirley, Brome and Suckling” which "also proved popular at particular times, Shirley's and Suckling's mainly in the first decade of the new regime" (CLARK 2001: 275). ${ }^{1}$ Unlike so much work on Restoration adaptation, the focus of this essay is not going to be on Shakespeare but about his later contemporary, James Shirley, a prolific playwright in the period 1629-1640. Born in 1596, Shirley survived into the Restoration and died, on $29^{\text {th }}$ Oct 1666 , in the most Restoration of fashions, as a result of the "affrightments, disconsolations and other miseries occasioned" by the Great Fire (WOOD 1691-1692: 1: 262). He, therefore, had the opportunity to see some of his own plays re-staged in the revived theatrical culture after 1660, though (alas) there is no textual record that he actually did so. This article will briefly set Shirley in his Restoration context and then go on to explore this afterlife specifically through Aphra Behn's engagement with his work, most directly in her The Lucky Chance (1686).

During the 1630s Shirley wrote in all genres, as the primary playwright of Queen Henrietta's Men based at the Cockpit. This indoor private playhouse, also known as the Phoenix, was planned and built in 1616 by the theatre manager Christopher Beeston. G. E. Bentley identified the exact site as being between Drury Lane and Great Wild Street, north-west of Princes' Street in the parish of St Giles in the Fields (BENTLEY 1941-1968: 4: 49). Unlike the outdoor amphitheatres which originally hosted (most of) Shakespeare's plays and the Blackfriars indoor theatre, the Cockpit's house was noticeably smaller, but the stage was about the same size as Blackfriars; it had galleries and two rectangular doors on either side of a central arched door (which may have been a discovery space). ${ }^{2}$ In other words, it was a theatre much more like those of the Restoration in size and intimate dynamics - though it did not, of course, benefit from a scenic stage. In both his love of asides and use of two simultaneous circulating conversations that alternate as the focus of a scene, Shirley can be seen as a dramaturgical precursor of the Restoration playwrights, facilitated in both theatres by the proximity of the seated audience to the proscenium.

Perhaps not surprisingly then, Shirley's plays did find favour on the Restoration stage. As Nancy Klein Maguire notes, of the 105 earlier plays revived before 1671, Shirley's 14 do compare surprisingly favourably with other playwrights, though this number is only half the 28 that she attributes to Fletcher (MAGUIRE 1992: 56). To put

1 See also (SORELIUS 1966; HUME 1976: 233 n.1).

2 For a description of the Shakespearean playhouses and their probable dimensions, see (GURR 2009: 139-208). Gurr notes that Gordon Higgott, an expert on Inigo Jones' drawings, is not convinced that the plans in Worcester College, long taken to be those of the 1616 Cockpit, are actually for this theatre. Higgott dates the plans to after 1660 and identifies the hand of John Webb (Jones' assistant), though, as Gurr points out, they could be a copy of an earlier design (GURR 2009: 201-202). 
this in perspective for the very beginning of restored playing, a rough count through The London Stage (up until the end of the second season of playing) shows that there are 13 performances of Shirley's plays, 16 of Jonson's and 15 of Shakespeare's. Maguire and Clark are correct about John Fletcher's pre-eminence - he had a hand in an astonishing 56 of the performances before the end of the 1661-1662 season, across 20 separate plays. Of these, the 5 performances of The Scornful Lady racked up the most repeats but another 6 of Fletcher's collaborations were given 4 times. ${ }^{3}$ Of the other Jacobean plays, there is more than one performance of The White Devil, a fad for A New Way to Pay Old Debts and a successful run of The Knight of the Burning Pestle. After Fletcher (to whom no other old playwrights' works come close in popularity), to the naked eye Shirley, Shakespeare and Jonson are out on a limb of their own. Anthony Wood tells us Shirley's plays were "acted with good applause" (WOOD 1691-1692: 1: 261). In fact, in the first two years of the Restoration (up until July 1662), eight of Shirley's plays appeared at the Red Bull (used for playing by Killigrew's company before the move to Gibbon's Tennis Court in Vere Street), at the Vere Street Theatre Royal itself and on a King's Company visit to Oxford. The most popular of these were his tragedies The Traitor (printed 1635) (given 4 times) and Love's Cruelty (printed 1640) (given 3 times). ${ }^{4}$ In the following few years, up to 1670, another 6 of Shirley's plays made it onto the stage: the King's Company with Hyde Park (printed 1637) and The Court Secret (printed 1654, but not played till the Restoration) and the Duke's Company making a late run from 1667 onwards with Love Tricks (printed 1631), The Grateful Servant (printed 1630), The Gentleman of Venice (printed 1654) and The Gamester (printed 1637). We know that another Shirley play, The Constant Maid (printed 1640), renamed Love Will Find Out the Way in its updated and enlarged Restoration incarnation, was reprinted in 1661. A performance of this play by the Nursery company has long been assumed from the title page of its 1667 reissue but never actually proved. ${ }^{5}$

What perhaps is most notable for a Shirley scholar from the list of Restoration Shirley performances, is what is not there. Neither The Bird in a Cage (printed 1633), nor The Lady of Pleasure (printed 1637) - what we might today consider to be Shirley's best comedies - seem to have been given, despite the latter's influence on Aphra Behn's The Lucky Chance (performed 1686). This essay will contextualise these two plays within the definite Restoration acceptance of - if not positively a fashion for - Shirley. It will investigate why they might have been absent from the Restoration stage, and go on to explore why The Lady of Pleasure is very much present in Behn's work. And the first

3 The Tamer Tamed, The Beggar's Bush, Philaster, A King and No King, Rule a Wife and Have a Wife, and The Nightwalker (interestingly, often attributed to Shirley).

4 Also given twice in the first two seasons were The Wedding, The Young Admiral, Love in a Maze; The Opportunity, The Brothers and The Cardinal. I am very grateful to my former student Hannah Davies for doing the number crunching on this, working on the project funded by a Warwick Undergraduate Research Studentship, available online at https://warwick.ac.uk/fac/arts/ren/archive-research/oupjamesshirley/ urssposters.

$5 \quad$ I am very grateful to Stefania Crowther for reading and commenting upon this essay. For a full audit and discussion of the plays of Shirley in the Restoration her PhD dissertation (CROWTHER 2017). 
question we must pose is why might The Bird in a Cage be in the least important in the Restoration, given that it was notably not revived?

\section{Women-Actors: Notorious Whores}

The explanation speaks to the most radical break with past playing, what Elizabeth Howe calls "an historic moment for English theatre", the arrival of the actress (HOWE 1992: 19). The Bird in a Cage directly addresses in its prefatory matter the problem of women playing women. In 1633, very pointedly, Shirley dedicated the play, ironically and (one feels) somewhat ungenerously, to William Prynne, whose anti-theatrical tract Histriomastix, or The Player Scourged had just landed its author in jail. The "infamous Puritan polemicist [...] issued the almost 1,000 page Histrio-Mastix as the ultimate denunciation of Caroline theater in all its forms - from public plays, to dancing, to private masques" (WHITMORE RARE BOOKS, n.d.). The very long anti-fun pamphlet took aim at everything the Puritans later banned - dancing and maypoles in addition to theatre - as well as appearing to criticise Henrietta Maria and her ladies, who took up amateur dramatics just as the unfortunate Prynne went to print. Histriomastix had already been licenced in 1630 and Prynne had clearly been working on its massive length for some time - since the 1620s, according to his assertion at his trial; (SANDERS 2006: 24). Surely even the religious fervour of the zealously righteous Prynne could not have foreseen the onset in January 1633 of Henrietta Maria's amateur dramatic fit, when she performed in Walter Montague's Shepherd's Paradise? In fact, Histriomastix came out in November 1632, well before the performance - though that had been long in the planning: the ladies had had difficulty learning their lines and the play had had to be postponed. However, Lamont does note that "Prynne had inserted additional criticisms of female actors in an appendix while Henrietta Maria was rehearsing for the event" and at least one entry in the index, too, must have spelled difficulty for Prynne:

Women-Actors, notorious whores. p. 162, 214, 215, 1002, 1003. Unlawfull. Ibid. Hence Justinian. Autenticorum Collat. 5. Tit. 4.f.46 enacted this Law [...]. And good reason: for S. Paul prohibites women to speak publikely in the Church. I Cor.13.34. I Tim 2.12. And dare then any Christian woman be so more then whorishly impudent, as to act, to speak publikely on a Stage, (perchance in mans apparel, and cut haire, here proved sinfull and abominable) in the presence of sundry men and women? [...] O let such presidents of impudency, of impiety be never heard of or suffred among Christians. ("The Table", Rrrrrr4r)

Seeming to call the Queen a "notorious whore" was obviously a mistake, especially when using St Paul's prohibition of women speaking publicly in the Church to argue that any woman speaking publicly on a Stage is guilty of "more than whorish impudence". It really must have appeared that Histriomastix was targeting the queen, or at least so Shirley affected to understand when he ranged himself on her side against Prynne. 
As his dedication encourages us to, Shirley's The Bird in a Cage could be read as a direct riposte to Prynne's prohibition of female acting because it features an interlude in which the Duke's daughter Eugenia and her ladies act out the story of Jupiter and Danae to amuse themselves. As Julie Sanders has noted, "Shirley's handling of female theatricals in The Bird in a Cage is full of ambivalences and contradictions, and cannot as a result be read as a straightforward defence of women and performance", but it was a good enough defence to get Shirley preferment from the queen and possibly to influence his being asked to write a masque, The Triumph of Peace, to be given at court by the Inns of Court on $3^{\text {rd }}$ February 1634 (SANDERS 2006: 25). There are problems with proto-feminist readings of The Bird in a Cage, as detailed by Sanders and earlier by Valerie Traub (1992) and Kim Walker (1991). Walker argues that The Bird in the Cage seeks to contain women's agency and that Shirley puts various strategies to work "recuperating such deviancy for patriarchy" (WALKER 1991: 400). It is true that the women are confined to a tower - like Danae - by Eugenia's impossible father who wants control, principally, of course, of her sexuality. And it is also true that he is not punished for this outrageous behaviour except in humiliation when her worthy suitor manages to get himself smuggled into the tower hidden in a column of an elaborate birdcage. Even at the end the Duke is overbearing: when he thinks that her faithful lover Philenzo is poisoned he pronounces that she not marry Florence now, I Nor any other, since Philenzo's dead" (The Bird in a Cage, 5.1.358-359). ${ }^{6}$ In fact he is more concerned with the continuation of his blood line than with her happiness: "Who now I Shall marry my Eugenia? I have undone | The hope of our posterity" (374-376). Fortunately, his daughter and her lover are cleverer than he is and, after the Duke has said he would have allowed them to marry if Philenzo were still alive, they are able to produce him unharmed. Eugenia herself is responsible for the happy ending, which relies both on her sexual self-control (she does not even contemplate running off with Philenzo) and on the self-control required to seem to conform to her father's dictates. She recognises that it is foolish to cross him openly, admitting her father's unreasonableness in an aside: "I know he is I Too passionate to be denied his will" (1.1.77-78). She respects the reality of the demands of what her father terms "filial piety" (1.1.90), and consoles herself with the thought that "I must obey | In hope it will not last" (1.1.83-84). There is an argument here that Eugenia's patience and good sense subvert patriarchal structures, though it may be more accurate to suggest that only badly - exercised patriarchal power has been conquered.

Nevertheless, the fact is that - whether we can read The Bird in A Cage as reclaiming patriarchal control or not - this is still a play which draws attention to female actors. The Jupiter-Danae interlude has attracted some scholarly attention for staging a playlet which cross-casts some characters - Donella as Jupiter, notably - and in which all of the actors are "notorious whores" in Prynne's formulation. It also stages the slippage from actor to character, with Donella, interrupted just at the point that Jupiter is about to ravish Danae, claiming that "An you had not waked as you did, madam, I should ha' 
forgot myself and played Jupiter indeed with you. My imaginations were strong upon me, and you lay so sweetly" (4.2.169-172). Valerie Traub uses the play to interrogate ideas of homoeroticism on the early modern stage and notes that this moment is

liminal [...] in the history of the relation between theatricality and sexuality, render[ing] problematic the use of those conventions that previously had governed depiction of female desire: the necessity of boy actors and the cross-dressing of homoerotically desiring female characters. (TRAUB 1992: 161-162)

But what she does not say specifically is that boys played all the characters in the playlet and that Donella's personation as Jupiter might be more accurately seen as a "dis-guise" than a disguise - a taking off of costume rather than adoption of it. Of course that begs the question of how the sexual dynamics operate in a play where the dis-guised character is male/male but the disguised is male/female, but this would be the subject of an essay about the theatricality of the 1630s rather than the Restoration.

However, the lack of a Restoration performance of The Bird in a Cage may not be unrelated to women playing women. Indeed, the playing of female parts by female actors, such as we saw in Montague's Shepherd's Paradise, and such as Shirley was exploring in The Bird in a Cage was, if hardly a non-issue, at least a different one in a Restoration context. The productive confusion of the cross-dressed playlet evaporates under Restoration conditions and indeed, one might suggest, becomes problematic - however much Pepys thought, for instance, "Nell, in her boys clothes, mighty pretty" (1893: Thursday 7 May 1668). Jonson's Epicoene was popular in revival, played at the start of the Restoration with Edward Kynaston in the title role, but the advent of actresses meant that by May 1663 Mary Knipp took this part and he was Dauphine. One might have thought that this play particularly would suffer from the 1663 casting decision - it being hard to "reveal" Epicoene as a boy all along when he is played by a woman. Howe suggests that Kynaston's performance as Epicoene was an attempt "to extract as much entertainment value as possible from his ability to impersonate women", a skill which was by then making him a "theatrical freak" (HOWE 1992: 25). As Robert Noyes noted long ago, "The anomaly of disguising a woman as a woman and then revealing her as a boy should have struck the sensibilities of witty Restoration audiences acquainted with The Country Wife" (NOYES 1935: 177). ${ }^{7}$ It might be borne in mind, given the affinity between Shirley and Behn being traced here, that the same witty audiences were also acquainted with The Rover, and its stage direction, "Enter Hellena, dressed in man's clothes" (4.2.197 SD). ${ }^{8}$ Noyes may be right in general but, of course, both new plays date from much later - 1675 and 1677 respectively - long after the first non-crosscast Restoration revivals of Jonson's comedy. So if The Bird in a Cage had been given on the 1660s stage, after 1663 at least one assumes that all the female roles would have been played by women and that Donella's "lesbian" scene would have become

7 See also (HAGGERTY 2009).

$8 \quad$ All quotations are from (BEHN 1995). 
so stripped of its layers of metatheatricality as to have presented a whole raft of new inferences. ${ }^{9}$ Both Howe and, more recently, Dawn M. Goode have written about the proliferation of breeches roles in new plays, but there has yet to be sustained attention to how this might have affected revivals of old plays which were not adaptations and not Shakespeare. But one thing that Goode does note is that, in common with Shirley, Aphra Behn particularly evinces a willingness to play with the possibilities of lesbian attraction - citing as evidence the burgeoning but never realised relationship between Mirtilla and the cross-dressed Endimion/Olivia in The Younger Brother (performed 1696 but written, obviously, before 1689) (GOODE 2013: 181). It is clear from her engagement with The Lady of Pleasure that Behn was reading Shirley in the mid-1680s, just as she was about to write The Younger Brother. For an author repeatedly recognised as Sapphic and hermaphrodite in scholarly discourse, The Bird in a Cage's playlet must have intersected fruitfully with her existing poetic sensibilities, as demonstrated in, for example, "To the Fair Clarinda" (1684). ${ }^{10}$

Nevertheless, there is a specific reason to use the story of Jove and Danae which is not primarily about narratives of sexual ravishment, notable though these are in both Shirley and Behn's poetry. Behn makes use of Danae in a "Song" first published in Westminster Drollery (1671), to reject the notion that love can be bought. The second stanza makes fun of Jove having to pay for sex:

Let Jove with Gold his Danae woo,

It shall be no rule for me:

Nay, 't may be I may do so too,

When I'me as old as he.

Till then I'le never hire the thing that's free. (Westminster Drollery, BEHN 1915: 6: 365)

This is consistent with all the other mentions of Danae in plays between 1660 and 1700 (PROQUEST English Drama database). As early at least as Beaumont and Fletcher's Philaster (c. 1610), and firmly by the Restoration, the story had become a type of transactional sex and, as such, we might want to reconsider Shirley's use in this light as well as paying attention to its possible sexual meanings. In The Bird in a Cage, Eugenia is her father's "rich [...] jewel" (1.1.92), and her diplomatic marriage to Florence is to be wholly transactional. Her physical confinement is a mere echo of the lack of autonomy she has in financial and practical terms. To "win" her freedom from her father, Eugenia must arrange that she marry for love alone; her anti-paradigm must be being wooed with gold. Philenzo's antic disguise as Rolliardo stresses the ludicrousness of attachment to money. His gambit to the Duke is that he is a man who will do anything for riches, even risk his life on a whim, parodying Volpone's hymn to gold in his assumption of the character of "a wild fellow" (1.1.252): "Divine money, the

$9 \quad$ Furthermore, the play would have been challenging in another way since there are a six such roles and presumably there might not have been enough actresses to take them.

10 See e.g. (TRAUB 2010). 
soul of all things sublunary [...] Money - it opens locks, draws curtains, buys wit, sells honesty, keeps courts, fights quarrels, pulls down churches, and builds almshouses" (1.1.242-243; 249-251). Rolliardo's understanding of wooing a lady is to "fall upon her, as Jupiter on Danae. Let me have a shower of gold, Acrisius' brazen tower shall melt again" (1.1.275-276). Shirley forces the Duke into the ironic position of having to defend his daughter, and women in general, from Rolliardo traducing them by claiming their love can be bought. These notions of transactional sex are further explored by Shirley in The Lady of Pleasure and in almost all of Behn's work, including The Lucky Chance as we will see later.

To help us to contextualise the moment in which Behn turned to Shirley, there is a final point to make about Epicoene. It is worth noting that The London Stage records no performances of Jonson's play between 1668 and 1685, reminding us again that there really is no such uniform thing as "Restoration drama". Crucially, however, the performance of Epicoene in 1685 was in the same season as a revival of The Rover - the plays were given on January $15^{\text {th }}$ and $22^{\text {nd }}$ respectively - and Behn's The Lucky Chance followed the next season, premiering in mid-April 1686 with Elizabeth Barry as Lady Fulbank. As Hume has pointed out, the period between 1682 and 1688 produced a tiny number of new plays (4 per year) in comparison to the years just before, where 1680-1682 saw on average 12 per annum. The final collapse of the King's Company in March 1682 saw the amalgamation of the players to form the United Company, and a consequent diminution of need for new work (HUME 1976: 340-341). With no competition, management policy became "acutely conservative", with "emphasis [...] on the revival of 'safe' old plays" (360), and "the reviveing of the old stock of Plays", as George Powell recalled in 1690 (361). In 1682-1688, The Rover, Epicoene and Bartholomew Fair, several of Fletcher's plays, and Brome's The Jovial Crew all appeared alongside earlier Restoration hits such as The Plain-Dealer and An Evening's Love. The repertory of yesteryear was revived just at the moment when Aphra Behn was about to fillet Shirley's The Lady of Pleasure for her The Lucky Chance, and this is probably not mere coincidence. Behn's influences for The Lucky Chance are firmly pre-Civil War. She draws heavily on Shirley's The Lady of Pleasure and surely also on Ben Jonson's The Devil is an Ass, whose virtuous wife is "rented" to her would-be lover by her worthless husband in exchange for a cloak, a plot point echoed by Behn when Sir Cautious loses the wager of a night with Lady Fulbank to Gayman. By 1686, Behn acknowledges the dearth of new plays in her "Prologue" to The Lucky Chance, commenting that "with old plays you have so long been cloyed" ("Prologue", 1. 1, BEHN 1995). However, the play is so dependent on motifs from "old stock" plays that her claim "We show you [a play] entirely new" (1. 41) hardly rings true. 


\section{Money for nothin' and chicks for free, or "I bequeath my lady to you, with my whole estate" (The Lucky Chance, 5.7.181-182)}

What Behn's work searches for more than anything is a way for the Restoration woman to be virtuously independent without sinking into abject poverty, an idea that Robert A. Erikson has applied specifically to The Lucky Chance. Both Shirley and Behn are interested in the preservation of outward virtue in their versions of the reverse bed-trick plots, in which the mistress arranges an assignation with her lover incognito, but their execution and solution are shaded differently. In Shirley's The Lady of Pleasure, Aretina (Lady Bornwell) is married to a man who, she claims, imposes thrift upon her spending and would prefer to be in the country than in London living the high life. From an audience's observations of him in the play, Bornwell actually seems eminently reasonable and more than a little indulgent of his wife's need to haemorrhage their substance. Shirley certainly does not expect his audience to side with her, and uses small things to undercut our sympathy - her pulling social rank over him in an attempt to berate him for thriftiness, for instance: "What charge more than is necessary for I A lady of my birth and education?" she snaps at 1.1.58. ${ }^{11}$ In fact, Bornwell's answer to this sums up the meat of the play's analysis of the problems of marriage:

I am not ignorant how much nobility

Flows in your blood: your kinsmen great and powerful

I'th'state. But with this lose not your memory

Of being my wife. I shall be studious,

Madam, to give the dignity of your birth

All the best ornaments which become my fortune. (Lady of Pleasure, 1.1.59-64)

Aretina's later accusation "I find you would entrench and wound the liberty I I was born with" (1.1.138-139) not only echoes with the language used to criticise Charles I's treatment of parliament ("entrenching upon" was a common seventeenth-century usage where the rights of the subject were threatened by the monarch, as the Oxford English Dictionary makes clear) but also offers a parallel to the virtuous Celestina's depiction of marriage later in the play. ${ }^{12}$ As a 15 -year-old widow, she notes that, though she was not unhappy in her marriage, she is not "fond | Of leaving the sweet freedom I possess | [To] court myself into new marriage fetters" (2.2.45-47). In comparison to both Fitzdottrel in The Devil is an Ass and Sir Cautious Fulbank in The Lucky Chance, Bornwell is a paragon of husbands. Despite Aretina's claims that he is prompted by avarice not "the handsome names of modesty and thrift" (1.1.137), he has done his best to make her happy:

11 All quotations from The Lady of Pleasure are from Huebert's edition (SHIRLEY 1986).

12 Martin Butler (BUTLER 1984: 171) argues convincing that Celestina in The Lady of Pleasure mounts a defence of her own rights when they are "encroached" upon by the Lord. Butler notes that this is the language of opposition to Charles I. 


\section{Have I not obeyed}

All thy desires: against my own opinion

Quitted the country, and removed the hope

Of our return by sale of that fair lordship

We lived in? changed a calm and retired life

For this wild town, composed of noise and charge? (Lady of Pleasure, 1.1.51-56)

In fact, Aretina's behaviour is less about spending power than it is about having her "pleasures circumscribed and taught" her (1.1.144). Her sense that she lacks liberty, that her husband treats her as a child, forces her to exercise that liberty in an extreme fashion: she arranges for Alexander Kickshaw, her gallant of choice, to be delivered to her chamber for a clandestine assignation by the delightfully - named Madam Decoy. Readers of earlier drama may struggle to process this plot device, because adultery on the stage of this period is irredeemably wicked and does not end well: from the anonymous Arden of Faversham (printed 1592) (husband ends murdered, wife and lover executed) to Thomas Heywood's A Woman Killed with Kindness (performed 1603) (lover banished; wife starves herself to death) to the ridiculousness of the multiple adulteries in John Marston's The Malcontent (printed 1604) (where no-one adulterous thrives at the end). ${ }^{13}$ The thing about Aretina, too, is that her husband is not unkind, nor stupid nor neglectful. In The Devil is an Ass by contrast, Mistress Fitzdottrel's husband is both stupid and venal, and her would-be lover Wittipol fits Volpone's (ironic) formulation: "Thou hast, in place of a base husband found I A worthy lover” (3.7.186-187; JONSON 1995). Sir Cautious Fulbank in The Lucky Chance is portrayed as something worse - Behn nearly goes as far as to represent this May to December marriage as legalised rape. We learn early "how fatal are forced marriages! | How many ruins one such match pulls on" (1.2.32-33). ${ }^{14}$ There are several hints, however, that Sir Cautious does not actually subject his wife Julia to too much within the marriage bed. He admits that "I danced so upon my wedding day that when I came to bed [...] I fell fast asleep, and slept till morning” (2.2.110-112). In Act 5 of Behn's play Lady Fulbank expresses doubt that the "alarm to love [... which] calls up every man's courage” will be answered with any physical action (5.4.3-5). Sir Cautious' rueful response aside "I doubt you'll find it, to my grief" tells its own story (5.4.6). Even so, Lady Fulbank's enquiry to Leticia after her supposed wedding night speaks volumes: "I was sick to know with what Christian Patience you bore the Martyrdom of this Night" (4.1.245-246). Behn does make it clear that perhaps the only thing worse than an impotent husband is an old man like Sir Feeble Fainwould, whose idea of courtship is calling his intended "pupsey" and "little puskin", and "Patting, and playing, and following her" (1.3.40; 44; 25-26). As poor Leticia feelingly puts it: "Heavens, what a nauseous thing is an old man turned lover" $(1.3 .56-57) .{ }^{15}$

13 Incidentally, there may be an echo in Aretina's rank-pulling of Alice's repeated reminders to her husband in Arden of Faversham that she is socially above him.

14 All quotations are from (BEHN 1995).

15 Of course, this hideous baby-talking love-making is quite common in Restoration drama, most famously perpetrated by Antonio in Venice Preserved (1681/1682) and Centlivre's The Busy Body (1709) which 
So there is a real difference between the moral impetus which propels Shirley's Aretina (Lady Bornwell) and Behn's Lady Fulbank towards their adulterous assignations. It is clear that Behn is directly following Shirley, though her touch is lighter - given that she has managed to dispose of many of the audience's scruples. She directly echoes Shirley in her description of the mysterious ancient incognita. In Behn, Gayman tells Lady Fulbank that the old Proserpine he met was "so rivelled, lean and rough: a canvas bag of wooden ladles were a better bedfellow" (4.1.83-84). Decoy's description of the night to come to Alexander Kickshaw in The Lady of Pleasure is clearly the derivation of Gayman's: "I shall not there affright thee, nor seem old, | With rivelled veins - my skin is smooth and soft | As ermine's" (4.1.75-77). The set-ups for the two incidents in The Lady of Pleasure, and in The Lucky Chance, are markedly similar: both Shirley's Alexander, blindfolded, and Behn's Gayman, with a dark lantern, enter the scene unable to see and are subsequently faced, respectively, with Decoy, and Pert dressed "like an old woman". A Chaucerian loathly-lady scenario is presented to both gallants, though Alexander is assured that his crone will transform when "our arms tie lovers' knots | And kisses seal the welcome of our lips" (The Lady of Pleasure, 4.1.73-74). Both men have been presented with serious amounts of money to get them to come, and their resultant sartorial finery has been already generally commented upon. Pert in The Lucky Chance stresses that "Fortune and love invite you" (3.3.22) and Alexander is moved by a mixture of "current gold" and fear of the "witch" into proceeding in The Lady of Pleasure. ${ }^{16}$ The last we see of Alexander before his assignation is this, as Shirley rather coyly ends the scene with him marching valiantly after the disguised Decoy:

I will have a strong faith, and think

I march upon a mistress the less evil.

If I 'scape fire now, I defy the devil. (The Lady of Pleasure, 4.1.96-98)

Behn, on the other hand, has much more fun in The Lucky Chance. Scene 3.4 has soft music, a song, Gayman expressing longing for Julia (Lady Fulbank) in her absence (or so he thinks), even as he prepares to prostitute himself to another, and then nymphs and shepherds both dancing and singing. It is difficult not to sympathise with Gayman when he says: "What the devil can all this mean?" (Lucky Chance, 3.4.65). He rules out the ceremony being an elaborate ruse to care for the lady's honour - as he puts it "It cannot be; this age affords none so nice" (3.4.68-69), and reckons it is to cover for her being old and ugly. His final words are sobering and, as he is at various points throughout the play, a little desperate:

Well, be she young or old, woman or devil,

She pays, and I'll endeavour to be civil. (The Lady of Pleasure, 3.4.75-76)

subjects Miranda to similar treatment from Sir Francis Gripe, though she at least is playing him to get her hands on her fortune which he controls.

16 This is reminiscent of Almachildes' reaction to Hecate in Thomas Middleton's The Witch (1616) and Alexander's mention of Hecate right at the end of the scene underlines this. 
The fun does not stop there. Because of the cross-plot involving Belmour and Leticia, Sir Feeble turns up in the middle of the night and disturbs the tryst, perhaps even before it can get going. Bredwell - Sir Cautious's apprentice and Lady Fulbank's factotum - manages to get Gayman out of the house both without him being caught and without him realising whose house it is, by dint of dressing them both up as ghosts and frightening Sir Cautious into a fit so that he face-plants on the floor. When Gayman next sees Julia he is forced to confess the whole incident to her - though he still does not know it was her - and one starts to wonder if her real motivation was to see if he trusted her love enough to confess. He has been hiding his increasing poverty from her for some time and she only knows about it because Bredwell acts as her informer. Certainly, one of the reasons she organises the elaborate plan is to relieve Gayman's needs by getting him to accept money, so that he does not have to keep sweet-talking (and by implication sexually servicing) his landlady into pawning her apostle spoons in order to feed and clothe him, and so that he can redeem the mortgage of which he has been cozened by Sir Cautious, Julia's husband. The reverse bed-trick comes rather as a surprise, since Julia has only indicated to Bredwell in scene 1.2 that she wishes to rescue Gayman financially and specifically directs that "I would not have him think it comes from me, for all the world; that nicety and virtue I've professed, I am resolved to keep" (1.2.106-108). The nicety and virtue seem to be as much directed towards the awkwardness of having a monetary hold over him as they do towards her reputation. One of the most interesting things about The Lucky Chance is the way that Behn subjects her hero, Gayman, to transactional sex in the way that is much more common for female characters in her plays and also other plays of the period. Gayman and Angellica Bianca in The Rover both sell the rights to their body for money, though Angellica at least has the sense to make an auction of it. Gayman's desperation at his financial ruin and the loss of his love are just as powerful as Angellica's love for Willmore and her gun-toting revenge. But his is also grubbier - his assignations with his landlady to "pay" the rent are the start of the slippery slope of prostitution to the unknown crone and he, unlike Angellica at the start, is not in control of the process. Behn's "Song", quoted above, where Jupiter buys his sex, surely chimes with Gayman's predicament when her speaker refuses to rent love and asserts "I court a Mistris, not a Landlady" (BEHN 1915: 365).

In The Lucky Chance, then, we can see a certain reversal of gender roles. There is a sense in which Julia is asserting her independence with this act of buying herself a lover, even if she only means to provide him with funds and not to exact physical recompense. It is not an action which just allows her power over Gayman either; she steals the money from her husband's counting house with a surprising lack of conscience, and an incident later in the play gives us pause for thought. When Sir Cautious rents a night with her out to Gayman for $£ 300$ (as part of a wager) and when she and Gayman clearly do consummate their relationship, she is very distressed. This may seem odd in the light of what an audience might have assumed her intentions to have been when she arranged their previous, ultimately abortive, assignation but she avows in the last scene that the plot was merely a test of Gayman's constancy, not a "design upon his person" (5.7.190). Bredwell corroborates this: "Believe me sir, 'tis true. I feigned a dan- 
ger near, just as you got to bed" (5.7.192-193). And if an audience remembers back to scene 3.5 and Bredwell's being surprised by Sir Feeble's sudden appearance, we are too polite to let on. But the transaction between Sir Cautious and Gayman which winds up the action of The Lucky Chance is a money-for-sex deal too - though one which is a gross abuse of power because patriarchy allows wives little agency and because Sir Cautious has profited from his marriage to Julia and, by betting on her chastity, uses her own substance to whore her out.

In Shirley's The Lady of Pleasure, on the other hand, Aretina definitely means to consummate her affair with Alexander as a result of the assignation, though even she, "appliable" as Decoy finds her to be, recognises the seriousness of the step she is about to take:

I blush while I converse with my own thoughts:

Some strange fate governs me, but I must on;

The ways are cast already, and we thrive

When our sin fears no eye or perspective. (3.2.349-352)

Alexander's gleeful report of his tryst with the hideous she-devil - all goblins, tails and insatiable hell-cats - and his intention to visit her again, for the money, snaps Aretina out of her stupidity: "Tis a false glass; sure I am more deformed. What have I done? My soul is miserable" (5.2.178-179). Interestingly Shirley has her confess her sin to her husband, and Bornwell forgives her. In giving Bornwell an opportunity to underscore his magnanimity, Shirley engineers his victory in the game of competitive profligacy that they have been playing. Bornwell had hinted to Aretina very early on that she was teetering on the edge of ruin:

Bornwell. I know not, madam,

But you pursue these ways.

Aretina. What ways?

Bornwell. In the strict sense of honesty, I dare

Make oath they are innocent. (1.1.154-157)

Once Aretina has accepted that she has overstepped the mark in taking a lover, she is forced back to the position they quarrelled about at the start of the play: "But with this lose not your memory | Of being my wife" (1.1.61-62). Bornwell's forgiveness is markedly fatherly, in that this is a literal re-inscription of patriarchal control, in Aretina's words: "I throw my own will off | And now in all things obey yours" (5.3.176-177). It is not made explicit, however, that Aretina confesses the whole to her husband and we may be meant to think of her mis-step as the catalyst that ensures she no longer pits her will again his, rather than a unique instance on the early modern stage of adultery forgiven by a sensible man. ${ }^{17}$ Bornwell's "Dearer now | Than ever to my bosom, thou 
shalt please | Me best to live at thy own choice" (5.3.179-181) really does not sound like the voice of an early modern man whose wife has just confessed to taking a lover.

Actually what may be most interesting about Behn's take on Shirley's plot device is that she goes out of her way to preserve the innocence of her heroine, who in so many other ways is both cynical and playful. In The Lucky Chance, it matters that Gayman and Julia were contracted in a love match before she was forced into marriage with Sir Cautious, it matters that there is real doubt about that marriage having been consummated and that Gayman has spent his not inconsiderable fortune trying to get Julia to have an affair with him in vain. The denouement is a bit of a fudge: despite Julia's fury that she has been tricked by him she is more angry when she discovers that Sir Cautious effectively sold her to her lover, and she forswears her husband's bed forever. Gayman calls her an "innocent adulteress" because "It was the feeble husband you enjoyed I In cold imagination [...] Till my excess of love betrayed the cheat" (5.7.27-28; 30). Sir Cautious's final act in the play is appropriate to comedy if not to reality, as he turns to Gayman and says "if I die, sir, I bequeath my lady to you, with my whole estate" (5.7.181-182). Unlike Shirley's Aretina, Behn's Julia has won the marital battle, and it is Sir Cautious who must "throw his own will off | And now in all things obey" hers. One cannot help feeling that this is pure wish-fulfilment on Behn's part, but - even so - note that Gayman, not Julia, gets control of the fortune. As in almost all seventeenth-century plays, either side of the civil war, the real focus is on money not sex.

So, finally, is it possible to come to some tentative conclusions about why Behn decided to rewrite Shirley? It is a political choice, of course, to use a notably Royalist playwright as your source, as Behn more famously did with Killigrew's Thomaso, and we might speculate that the accession of James II and the aftermath in 1685-1686 (when she must have been writing The Lucky Chance) lent particular weight to this decision. Roy Booth has noted that Behn's rewriting of the reverse bed-trick device shows "the leading female dramatist of the Restoration finding in Shirley an anticipation of the effects she needed" (BOOTH 2010: 169). But Shirley's play is really too bleak and too moral for the Restoration - even for the 1680s. The Lady of Pleasure is not a fun play, in the way that, say, another Shirley town comedy Hyde Park (published 1637) is. But Behn deliberately makes the denouement of The Lucky Chance comic - largely because, as Sir Feeble rightly points out to Sir Cautious "we are a couple of old coxcombs, d'ye hear, sir, coxcombs" (5.7.179-180). But there is an anticipation, especially within the negotiated relationship between Julia and Gayman, of William Congreve's Millimant and Mirabelle in The Way of the World (1700). Their marriage is tested before it can even start. And there is another important question: if we did not know the author of The Lucky Chance was a Tory would we read bits of the play differently? Of course, the two ancient alderman are the CityWhig butts of typical Royalist jokes. Sir Cautious breaks his moral and marital contract with his wife by prostituting her to Gayman - and an audience only finds it funny because it is Gayman, her "rightful" mate. Sir Cautious, though, only recognises him as Julia's former suitor after the fact, so cannot excuse his unhusbandly actions that way. His behaviour is, in fact, outrageous. As a result of this, Julia can refuse to keep her part of the marital bargain, and absents herself permanently from his bed. With the echo of Aretina's plea 
for individual liberty ringing in her ears, Behn seems to be edging towards contract theory of government at least in marital microcosm. So it is key in the play that the preexisting contract between Gayman and Julia, and the one between Leticia and Belmour, is represented as the true marriage. It may seem slightly fanciful at first to think of Gayman as a refraction of the true king to whom allegiance is due, and of the aldermen as parliamentary interlopers but this is a nuance that Behn inherits from Shirley. Bornwell in The Lady of Pleasure is a political statement too, in that he represents - even down to his cratylic name - the claims of the country party, and of Shirley's later patron the Duke of Newcastle, to the king's ear, over non-aristocratic interlopers. We have seen Behn, and many other Restoration writers, replay again and again the quarrels that caused civil war, and The Lucky Chance, with Shirley's influence, proves no exception.

This article has emphasised the unrecognised popularity of James Shirley's plays on the Restoration stage, demonstrating that - after Fletcher - Shirley, Shakespeare and Jonson pegged pretty level in the 1660s when it came to revivals. Aphra Behn's use of The Lady of Pleasure in her later play, The Lucky Chance, has raised questions about why neither Shirley's popular The Lady of Pleasure nor The Bird in a Cage were revived in the Restoration. Behn must have been reading Shirley in the 1680s rather than simply recollecting the plot since there are direct verbal echoes in her play from Shirley's dialogue, as her repetition of "rivelled" shows. This argues for a direct engagement with old plays, which is also apparent in her rewriting of Killigrew's Thomaso as The Rover. Scholars repeatedly connect The Bird in a Cage to Behn because Shirley's playlet leaves room for a lesbian desire which reverberates also within Behn's poetry and other drama. Evidence from Behn's poetry and in The Younger Brother demonstrate her probing the limits of same-sex sexual desire in ways that resonate also through The Bird in a Cage. Furthermore, Shirley and Behn share an interest in the politics of transactional sex, themes which run through both Shirley plays and also in so much of Behn's writing, and which are commonly conjured up by the story of Jupiter and Danae, the subject of the playlet in The Bird in A Cage. The Lucky Chance follows both Shirley plays in showing the negotiations necessary for women to remain both independent and virtuous in a system stacked against them. In a twist to her normal practice, Behn explores the possibility of a male protagonist being forced by desperate financial circumstances to prostitute himself. This is a plot device gleaned from Shirley, whose Alexander Kickshaw, though considerably less desperate than Behn's Gayman, values the payment he receives from his tryst much more highly than the sexual favour conferred. The sexual transactions of The Lucky Chance provide an escape for its abused heroine from her odious marriage, but both Shirley's plays are structured to reintegrate their female characters into the existing status quo. In The Lady of Pleasure, Aretina learns to exercise liberty within bounds and be happy, while Eugenia's patience and intelligence in The Bird in a Cage circumvent her father's tyranny. Behn's choice of Shirley as an influence, and of The Lady of Pleasure as a direct source, seems to have been both a political and an aesthetic decision - using a Royalist playwright underscores her Tory credentials even when her writing sometimes seems to edge towards ideas which Shirley would have found deeply radical. 


\section{Bibliography}

BEHN, Aphra. 1995. The Rover and Other Plays. Jane Spencer (ed.). Oxford: Oxford University Press, 1995.

BEHN, Aphra. 1915. The Works of Aphra Behn. Montague Summers (ed.). 6 vols. London: William Heinemann, 1915.

BENTLEY, G. E. 1941-1968. The Jacobean and Caroline Stage: Dramatic Companies and Players. 7 vols. Oxford: Clarendon Press, 1941-1968.

BUTLER, Martin. 1984. Theatre and Crisis 1632-1642. Cambridge: Cambridge University Press, 1984.

BOOTH, Roy. 2010. Caroline Theatre. In A New Companion to English Renaissance Literature. Michael Hattaway (ed.). Oxford: Blackwell, 2010: 166-175.

CLARK, S. 2001. Shakespeare and Other Adaptations. In S. J. Owen (ed.). A Companion to Restoration Drama. $2^{\text {nd }}$ ed., Oxford: Blackwell, 2008. Available online at https://doi. org/10.1002/9781118663400.ch16. [Accessed 6 Jan. 2021]

CROWTHER, Stefania. 2017. James Shirley and the Restoration Stage. Unpublished PhD thesis, University of Warwick.

ERIKSON, Robert A. 1996. Lady Fulbank and the Poet's Dream in Behn's Lucky Chance. In Broken Boundaries: Women and Feminism in Restoration Drama. Katherine M. Quinsey (ed.). Lexington, KY: University of Kentucky Press, 1996: 89-110.

GOODE, Dawn M. 2013. "Under a Petticoat": Excess Femininity and Lesbian Desire on the Restoration and Early Eighteenth-Century British Stage. Journal for Eighteenth-Century Studies 36 (2013): 177-190.

GURR, Andrew. 2009. The Shakespearean Stage 1574-1642. 4th ed., Cambridge: Cambridge University Press, 2009.

HAGGERTY, George E. 2009. "The Queen was not shav'd yet”: Edward Kynaston and the Regendering of the Restoration Stage. The Eighteenth Century 50:4 (2009): 309-326.

HOWE, Elizabeth. 1992. The First English Actresses: Women and Drama, 1660-1700. Cambridge: Cambridge University Press, 1992.

HUME, R. D. 1976. The Development of English Drama in the Late Seventeenth Century. Oxford: Clarendon Press, 1976.

JONSON, Ben. 1995. Volpone (1606). In Gordon Campbell (ed.). The Alchemist and Other Plays. Oxford: Oxford University Press, 1995.

LAMONT, W. 2011. Prynne, William (1600-1669), pamphleteer and lawyer. Oxford Dictionary of National Biography. Available online at https://0-doi-org.pugwash.lib.warwick.ac.uk/10.1093/ ref:odnb/22854. [Accessed 7 Jan. 2021]

MAGUIRE, Nancy Klein. 2005. Regicide and Restoration: English Tragicomedy, 1660-1671. Cambridge: Cambridge University Press, 2005.

MARSDEN, Jean I. 1991. Rewritten Women: Shakespearean Heroines in the Restoration. In Jean I. Marsden (ed.). The Appropriation of Shakespeare: Post-Renaissance Reconstructions of the Works and the Myth. Hemel Hempstead: Harvester Wheatsheaf, 1991: 43-56.

NOYES, Robert Gale. 1935. Ben Jonson on the English Stage 1660-1776. New York/London: Benjamin Blom, 1935.

PEPYS, Samuel. 1893. The Diary of Samuel Pepys, transcribed by Mynors Bright from the shorthand manuscript in the Pepysian Library, Magdalene College, Cambridge; edited with additions by Henry B. Wheatley. New York: Random House. Available online at https://www.pepysdiary.com. 
PROQUEST, n.d. English Drama Database. Available online at http://www.proquest.com.

PRYNNE, W. 1633. Histrio-mastix The players scourge, or, actors tragedie. London: Printed by E[dward] A[llde, Augustine Mathewes, Thomas Cotes] and W[illiam] I[ones] for Michael Sparke. Available online at http://0-search.proquest.com.pugwash.lib.warwick.ac.uk/books/ histrio-mastix-players-scourge-actors-tragædie/docview/2240852716/se-2?accountid=14888. [Accessed 7 Jan. 2021]

ROBERTS, Suzanne. 1994. Representations of Chivalry, Gender Relations and the Roles of Women in the Plays of James Shirley. Unpublished PhD thesis, University of Adelaide, 1994.

SANDERS, Julie. 2006. The Bird in a Cage by James Shirley. In Hero Chalmers, Julie Sanders and Sophie Tomlinson (eds.). Three Seventeenth-Century Plays on Women and Performance: The Wild-Goose Chase by John Fletcher, The Bird in a Cage by James Shirley, The Convent of Pleasure by Margaret Cavendish. Manchester: Manchester University Press, 2006.

SHIRLEY, James. 1986. The Lady of Pleasure (1637). Ronald Huebert (ed.). Manchester: Manchester University Press, 1986.

SORELIUS, Gunnar. 1966. 'The Giant Race Before the Flood': Pre-Restoration Drama on the Stage and in the Criticism of the Restoration. Uppsala: Almqvist \& Wiksell, 1966.

TRAUB, Valerie. 1992. The (In)Significance of 'Lesbian' Desire in Early Modern England. In Susan Zimmerman (ed.). Erotic Politics: Desire on the Renaissance Stage. London: Routledge, 1992: 150-169.

TRAUB, Valerie. 2010. 'Friendship So Curst': Amor Impossibilis, the Homoerotic Lament and the Nature of Lesbian Desire. In John C. Beynon and Caroline Gonda (eds.). Lesbian Dames: Sapphism in the Long Eighteenth Century. London: Routledge, 2010: 9-44.

VAN LENNEP, W., E. L. AVERY, A. H. SCOUTEN, G. W. STONE and C. B. HOGAN. 19601968. The London Stage, 1660-1800: A calendar of plays, entertainments E afterpieces, together with casts, box-receipts and contemporary comment: Compiled from the playbills, newspapers and theatrical diaries of the period. 5 vols. Carbondale, Illinois: Southern Illinois University Press. Available online at https://www.eighteenthcenturydrama.amdigital.co.uk/LondonStage/Database. Marlborough: Adam Matthew Digital, 2016. [Accessed 6 Jan. 2021]

WALKER, K. 1991. "New Prison": Representing the Female Actor in Shirley's The Bird in a Cage (1633). English Literary Renaissance 21 (1991): 3: 385-400.

WHITMORE RARE BOOKS, n.d. Histrio-Mastix. The Players Scourge, or Actors Tragaedie. by William Prynne Available online at https://www.whitmorerarebooks.com/pages/books/2155/ william-prynne/histrio-mastix-the-players-scourge-or-actors-tragaedie. [Accessed 7 Jan. 2021]

WOOD, A. 1691-1692. Athence Oxonienses. 2 vols. London: printed for Thomas Bennett, 16911692. 


\section{Dr Teresa Grant}

Department of English and Comparative Literary Studies,

University of Warwick, Coventry, CV4 7AL, UK

t.grant@warwick.ac.uk

Teresa Grant is Associate Professor in Renaissance Theatre at the University of Warwick, UK. She is a general editor of Oxford University Press's The Complete Works of James Shirley (15 vols; forthcoming from 2021). She has also, inter alia, edited collections and published essays on animals on the stage, history plays and translations of Seneca. 